\title{
THEMATIC PARALLELS IN SHAKESPEARE AND THE 19th CENTURY URDU POETRY: A COMPARATIVE STUDY
}

\section{PARALELOS TEMÁTICOS EM SHAKESPEARE E A POESIA URDU DO SÉCULO XIX: UM ESTUDO COMPARATIVO}

\author{
Muhammad Imran \\ University of Sahiwal, Sahiwal, Punjab, Pakistan \\ imranjoyia76@gmail.com \\ Muhammad Afzaal \\ Foundation University, Rawalpindi, Punjab, Pakistan \\ muhammad.afzaal1185@gmail.com \\ Neelum Almas \\ Foundation University, Rawalpindi, Punjab, Pakistan \\ neelumalmas@fui.edu.pk \\ Hammad Mushtaq \\ hamaadhashmi@gmail.com
} National University of Sciences and Technology, Islamabad, Pakistan

Abstract: This paper highlights that although Urdu poetry in the 19th century and English in Shakespeare's time is the embodiment of two different cultural, social, religious, and environmental factors, in their basic philosophies, both shared much that seems to be brought from a similar realm of thought. In this paper, the authors focus only on the thematic comparison of the key ideas, concentrating on topics and themes familiar in that time like life and death, love, self-praise, compensation theory, immortality, loss and exile, and music. This paper further discusses how Shakespeare's sonnets and plays and Urdu poetry of the19th century poets Ghalib, Mir, Zafar, and Zauq presents common human concerns regardless of geographical boundaries and time.

Keywords: Urdu poetry; Shakespeare; Universal ideas; Subcontinent; Human nature

Resum0: O presente artigo destaca que, apesar da poesia Urdu no século XIX e o Inglês no tempo de Shakespeare serem a personificação de dois diferentes fatores culturais, sociais, religiosos e ambientais, em suas filosofias básicas, as duas obras compartilham muito daquilo que aparenta ser originário de um mesmo domínio de pensamento. Neste artigo, os autores focalizam apenas na comparação temática de ideia centrais, concentrando-se em tópicos e temas familiares naquele tempo, como vida e morte, amor, o elogio de si mesmo, teoria da compensação, imortalidade, perda e exílio e música. O artigo discute também como os sonetos e peças de Shakespeare e os poetas Ghalib, Mir, Zafar e Zauq, da poesia Urdu do século XIX, apresentam inquietações comuns apesar das fronteiras geográficas e temporais.

Palavras-chave: Poesia Urdu; Shakespeare; Ideia universais; Subcontinente; Natureza humana

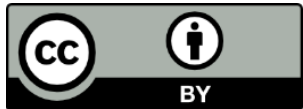


This paper analyzes similar themes and ideas expressed in Shakespeare's selected writings and Urdu poetry in the $19^{\text {th }}$ century from the Indian Subcontinent. ${ }^{1}$ There are many reasons which have let the authors to compare Shakespeare with Urdu poetry of the said era. Firstly, Urdu was the most widely celebrated poetic language in India in the $19^{\text {th }}$ century and had primary importance in literary and royal circles. Secondly, Urdu poetry's independence of ideas and thoughts was free from Western influence or association; the age produced new words and novel ideas in Urdu poetry. Shakespeare's universality and dynamic approach in English literature has continued to inspire critics and readers alike. Shakespeare's present time popularity in South Asian (Indian and Pakistani) academia, literature, cinema, and theatres ${ }^{2}$ is another reason for choosing him for the present discussion. Shakespeare is not limited to any specific age or region as Emerson wrote, "It was not possible to write Shakespeare's history till now,". ${ }^{3}$ In The Oxford dictionary of literary quotations, Kemp mentions Ben Jonson's famous saying attests to Shakespeare's universality that 'He was not of an age, but for all times' (Kemp 272). Therefore, the present essay takes Shakespeare and Urdu poets into account, highlighting the similarities of themes and ideas presented in two different languages that represent diverse cultures. The increasing popularity of Urdu poetry in European countries and their interest in the poetry of South East Asia is fascinating the Europeans and their civilization (Graham 1974). Being humans, emotions, and feelings are necessary for life irrespective of region, caste, creed, or even language. So, poetry becomes the language of those feelings and helps to make catharsis. Sometimes, the intensity, description, and examples highlight the proposed notions in the poetry of different regions and periods and the different languages observed the same without copying or imitating any idea or thought from other languages and literatures. While reading a piece of literature either in English or Urdu language one comes across the similar ideas and intellectual approaches towards certain themes, which amazes the reader. Mirza Ghalib, Momin, Mir Taqi Mir, Ibrahim Zoqu, the last Mughal Emperor of India Bahadur Shah Zafar, and Jaleel Manikpuri are the most celebrated figures in the 19th century Urdu poetry. They have rendered remarkable efforts to nourish literature by enriching not only the Urdu language but also the thoughts in Urdu literature. Brian Silver writes that for a comprehensive understanding of the Indo-Muslim culture and society, it is necessary to be familiar with the Urdu Ghazals of that time. Without knowing about Urdu Ghazal, literary exploration is incomplete. The genre of Urdu Ghazal is shaped by the master practitioners within the framework of Indo-Muslim culture's traditional perspectives. According to Brain Silver, Urdu Ghazal is dynamic in its phonetic manipulation techniques, comparisons, and contrasts, ellipsis,

\footnotetext{
${ }^{1}$ Urdu poetry up to $19^{\text {th }}$ is selected because of the fact that all Urdu poets selected for this essay were unfamiliar with English literature, especially from Shakespearean works. The basic purpose of comparing these English and Urdu poets is that there was no common readership of English Literature existed in India before 1875 and especially among Muslim families as it was considered unpatriotic to read and write in English. However, it was with the establishment of Muhammadan Anglo-Oriental College at Aligarh in 1875 by Sir Sayyid Ahmad Khan that the Muslim of colonized India started taking interest in Western Academia. See for details Graham, G. F. I. (George Farquhar Irving) The life and work of Sir Syed Ahmed Khan (New and revised ed., reprinted / with a new introduction by Zaituna Y. Umer). Oxford University Press, Karachi; London, 1974.

${ }^{2}$ Mark Brown in an essay 'Shakespeare more popular abroad than in Britain', expanded in The Guardian magazine on Monday $18^{\text {th }}$ April 2016 by Mark Brown. See the essay https://www.theguardian.com/culture/2016/apr/19/shakespeare-popular-china-mexico-turkey-than-ukbritish-council-survey

${ }^{3}$ See, for instance, John Hollander: Melodious Guile, Fictive Patterns in Poetry, Yale University Press, 1988. The second chapter, entitled 'Questions of Poetry' is devoted to the possibilities of semantic richness in the interrogative.
} 
interrogative forms, rhyme schemes, allusions, parallelism, paradox. And kinetics in imagery are the notable features of Urdu poetry up to the $19^{\text {th }}$ century (Sliver 2016).

While reading Shakespeare's plays and sonnets, it is observed that many ideas resemble the thought expressed by the Urdu poets of the Mughal era in India. Although, English poetry of Shakespearean time has a typical disagreement in almost all basic norms and tenets from Urdu poetry in composition due to differences of time, social and cultural context, geographical boundaries and language variation, perspectives such as the Urdu poetry of that time revolves around ghazal and every ghazal somehow addresses to 'Mahboob' ${ }^{4}$ a typical word used for beloved, but in English poetry, it is quite different in approach and sensitivity especially towards the addressee.

The theme of life and death has a significant part in Shakespearean and Urdu poetry. In Shakespeare's most celebrated soliloquy in the play Hamlet 'To be, or not to be' in (Act III, Sc. I) Hamlet, the protagonist of the play, has been musing about the circumstances around him and on the alternative to find out from the two choices: life or death. He makes contemplates and thinks of bearing the hardships and of injustice or to take decisive action against the overwhelming powers. He also contemplates the reality of death, is it just a state of sleep, a departure from the worldly existence, relief from the sorrows and end of all troubles, or whether there may be something more grave and painful waiting for us after death. This famous soliloquy is reflective of meditation on life and death, and a conflict that man faces in terms of finding peace in the world by taking matters in one's own hand and setting things right for himself or to let death bring an end to all sorrows.

A famous Urdu poet of the $19^{\text {th }}$ century Sheikh Mohammad Ibrahim Zauq (1790-1854) has described the same idea and theme artistically in his Ghazal,

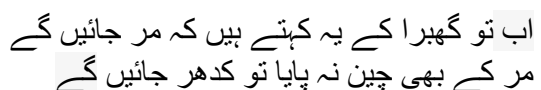

[Being agitated I express the hope to die, although in death,

if solace is not found, then where shall I go?] ${ }^{5,6}$ (Zauq 2018)

The poet has expressed his fear about fruitless escapism from worries and hardships of life in the shape of death because after death he does not know what will happen and where he would find a refuge and peace if something terrible is awaiting him after death. In both the writers' pieces, the common theme observed is 'the immortality of the soul' and a strong belief that all human beings have a mortal body and immortal soul. Shakespeare has crafted unique images to describe the scene of the departure of the soul from the body. His words 'To die, to sleep' refers to death as a type of sleep, and at another place in the same soliloquy, he determines that the fear of death is not the fear of complete annihilation and invisibility of man instead he is worried about the life after death. The fear of the unknown sufferings and uncertainties a person has to face after death makes him anxious. There are many other places in Shakespeare's works where he discusses immortality, for example, in Antony and Cleopatra, Cleopatra describes her longings of immortality and says, 'Give me my robe, put on my crown; I have/immortal longings in me. Now no more/the juice of Egypt's grape shall moist this lip'

\footnotetext{
4 'Mehboob' it is a typical word used for beloved in Urdu and every romantic and love based ghazal revolves around this character.

${ }^{5}$ All translations from Urdu to English are done by the author of this essay.

${ }^{6}$ All translations of Urdu verses into English are done by the writers themselves.
} 
(Shakespeare 2018) (Antony and Cleopatra, Act V, Sc. II). In his sonnet 146, he describes in detail the theme of immortality and the duality of body and soul and used the phrase 'fading mansion' regarding the body and the concluding lines sum up that the physical body will be destroyed and the soul remains forever as there is no more death after this bodily death. $\mathrm{He}$ says, 'and the death once dead, there's no more dying then'. (Shakespeare, Sonnet 146, line: 14)

The ideas of sadness and sorrow are equally present in Mir Taqi Mir (1722-23-1810) as in Shakespearean writings. A famous critic of Urdu poetry, Majnun Gorakhpuri, ${ }^{7}$ sees Mir Taqi Mir as a revolutionary Urdu poet, who introduced new trends and modern approaches in subject matter and themes. He has observed moral, revolutionary, and didactic thoughts in his poetry and titled him the poet of sorrow by claiming that; Mir is the poet of sorrow. Mir's age was the age of sorrow. If Mir, had not been the poet of sorrow he would have committed treason against his age, and would not have been such a great poet for us either (Gorakhpuri 196). Another well-known critic of Urdu poetry specifically Mir's poetry is Maulvi Abdul Haq (1929), who also takes his poetry as serious and filled with sorrow that even in his comic poems he finds sorrowfulness (16-31). Abdul Haq references Mir's famous verse to prove his thesis that he shows the signs of sorrow and despair in the comic tone.

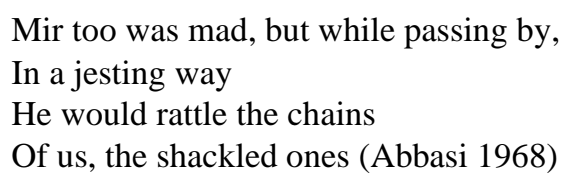

So, Mir Taqi Mir has an excellent approach towards the use of words and tone as his humor was mature and pregnant with multiple layers of meanings. From these remarks, the readers can easily conclude that Mir's poetry has a variety of themes including tragic and comic mixture, however, his poetry is the voice of his time to reflect the anguish and pain in a very light and gentle manner.

The theme of love is the most celebrated theme in the Urdu poetry of the $19^{\text {th }}$ century and Shakespeare's poetry. In Urdu ghazal, the dominant themes of love, and descriptions of the feelings of a lover, and beloved are present in abundance. The size of a ghazal and Shakespearean sonnet is almost equal but their way of dealing with these themes is different. In Urdu ghazal, general ideas about love and the beloved's beauty are commons, however, in Shakespeare's sonnets the idea of love tends towards the idea of Platonic love and it's relevant to Shelley's 'Hymn to Intellectual Beauty' (1817) based on pure and abstract beauty that reflects from the actions and sentiments of human beings. Urdu poet Jaleel Manikpuri (1866-1946), as Shakespeare in his sonnet number 130, describes the beauty of his beloved and traditionally praises her beauty, but in reality, shows that nothing looks charming and beautiful like his beloved. In the first eight lines, he describes the beauty of his beloved through a conventional device of comparison but in the last six lines, he describes the matchless beauty of his beloved beyond any comparison. Shakespeare writes in sonnet 130:

My mistress' eyes are nothing like the sun;

Coral is far more red than her lips red; (Shakespeare 2018)

\footnotetext{
${ }^{7}$ Majnun Gorakhpuri's essay was first published in the 1940's and later in M. Habib Khan's edited book Afkar-e Mir in Delhi by Abdul Haq Academy first edition in 1967 and second edition in 1996.
} 
And in the last lines, he concludes the sonnet with the praise of his beloved and says that his mistress is the most beautiful and matchless lady in the world. The whole idea of the sonnet is compressed in the following couplet by Manikpuri;

[Eyes are not lightning, the face is not sun'

$$
\begin{aligned}
& \text { نحاه برق نهيب جهبره آفتاب نهبي }
\end{aligned}
$$

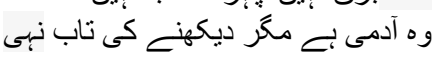

That is a person, but have no endurance to glance at] (Manikpuri 2018)

Jaleel Manikpuri has laid stress on describing his beloved's personality traits in an unconventional way as Shakespeare has done in his above-mentioned sonnet. In sonnet 53, Shakespeare admires the everlasting beauty omnipresent in all manifestations of nature's beauty and reflects in actions and behaviours of human beings.

Shakespeare and Urdu poets have frequently used the theme of weariness from this mortal world for example in his comedy play, Twelfth Night, Shakespeare has described the scene of inviting death by Feste, the Clown, in play in Act II and Scene IV. Shakespeare in his play says that:

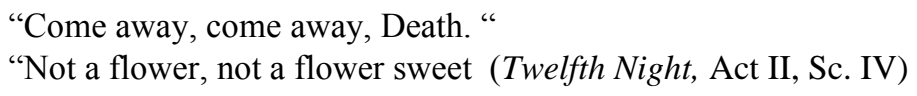

Interestingly, Mirza Ghalib (1797-1869), the most influential Urdu poet, has described the exact theme in his ghazal and says;

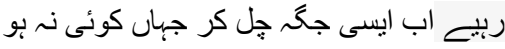

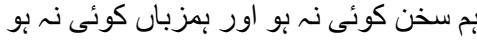

[To go and live in such a place where no one else should be No one there to share one's thoughts no soul for the company] (Ghalib 2018)

In these verses, Shakespeare and Ghalib: the best among poets of their ages and languages reflected the same thought of weariness from this mortal world and its existence and wished to be absolved from all the worldly concerns and contacts. The two examples are closely interconnected in content and themes because the world's weariness is due to its problems and worries. The killing is in the sense of destroying someone with a sensuous look. The slaying of the lover by beloved in both Urdu and Shakespeare's poetry is a common motif. In the Twelfth Night, Shakespeare describes this theme in the following words:

Come away, come away death,

My part of death no one so true

Did share it. (Twelfth Night, Act II, Sc. IV)

Metaphorically, Shakespeare has highlighted the cruel behavior of the beloved, the beloved's slaying attitude for a lover, burial, and enshrouding of the lover, and finally lover's desire to haste to death (Kochar 2020). The same themes are vividly enunciated in Urdu Ghazal. Mirza Ghalib describes the same theme of brutality and ruthlessness of his beloved's behavior in his famous ghazal. He is the first modern Urdu poet who has adopted a change in the ideas of poetry as well as in its form. That's why he is viewed as standing at the crossroads of modern history and literary culture. He has portrayed the mental and psychological fears and uncertainties of a man about death and its sufferings. In his poetry, he has repeatedly described the painful nature of death. 


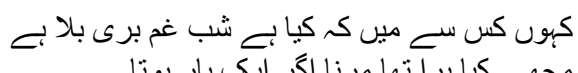

[Of gloomy nights alone and sad, to whom should I complain?

Dying just once would not be bad, but each evening again?] (Ghalib 2018)

In these verses, Ghalib describes his misfortune and desire to meet his beloved but he waited for this longing in vain. He has also remembered the arrows (a metaphor for beloved's cruelties), worries, and death. Parting with the beloved is equal to death. He expresses that he has to undergo the pain of death every day.

The compensation theory is also shared between Urdu poets of the $19^{\text {th }}$ century and Shakespeare as all human actions in this world either good or bad will have consequences after all. Emerson in his essay on 'Compensation' (1841) described the consequential nature of human actions in this world. He said, 'every secret is told, every crime is punished, every virtue is rewarded, every wrong is redressed, in silence and certainty. What we call retribution is the universal necessity by which the whole appears wherever a part appears' (Emerson 1900). In the opening lines, three witches in Shakespeare's tragedy Macbeth sing a sinister song in which they repeat the phrase: 'Fair is foul and foul is fair; Hover through the fog and filthy air' (Ben Amor 2020). The theme of the whole play is a dramatic confirmation of Emerson's theory of compensation, as Shakespeare aims to dismiss the devilish theory to consider fair as foul and reinstating that the truth and virtue are always rewarded and foul is still foul. In King Lear, the perfect example is Lear himself who suffered due to his injustice at the start of the play with his youngest daughter and he admits that he is being punished due to that act of injustice. In the historical play King Richard II, Shakespeare describes the consequences of King Richard's negligence of public affairs and office. King Richard in his last speech admits that

I wasted time, and now doth time waste me;

For now, hath time made me his numbering clock: (Richard II: Act. V, Sc. V)

After being dismissed from the court, King Richard II was put into prison by his cousin Bolingbroke, thus lamented on his lot and repented on his misfortune and described his griefs. Shakespeare truly presented an analysis of a humanist character who admitted his wrongdoings and repented upon them to find a way for catharsis.

That bucket down and full of tears am I,

Drinking my griefs, whilst you mount up on high. (Richard II: Act. IV, Sc. I)

After discussing his misfortune and helplessness, King Richard II further describes his mental situation and life in imprisonment along with his negligence of public office on which he is embarrassed. He is regretful that he wasted time and resources and says;

Mount, mount my soul! Thy seat is up on high;

While my gross flesh sinks downward, here to die. (Richard II: Act. V, Sc. V)

The poetic expressions and choice of themes and ideas of Bahadur Shah Zafar (17751862), the last Mughal King of India and a great Urdu poet and King Richard II, have similar repentance upon their loss of kingdoms and imprisonment. Shakespeare highlighted through this historical play the game of power between rulers similarly Bahadur Shah Zafar wrote his autobiography during the downfall of his kingdom in his poetry. 
In his last poems, he described his loss and the tragic life in exile with repentance and admits his defeat against the British Army in the war of 1857. He writes that:

[My heart has no repose in this despoiled land

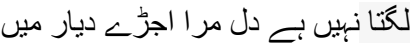

$$
\begin{aligned}
& \text { كس كى بنى بـ لهـ عالم نايائيدار مين ديار مين }
\end{aligned}
$$

Who has ever felt fulfilled in this futile world?] (Zafar 2018)

This poem explains the whole story of the last Mughal Emperor Bahadur Shah Zafar's regret, misfortune, and mortality of this worldly existence and his wish to be buried in his homeland where he and his ancestors ruled like gods for many years. Mirza Ghalib expressed his compensational thought in his well-known ghazal, 'Visaa'le Yaar' translated as union with beloved, in an interesting dialogue with himself. He summarizes his unfortunate lot in this ghazal as a central theme and curses himself for not being blessed with the company of his beloved. In the last verse of this ghazal, he lays stress on his qualities for being a philosopher and excellent poet as these qualities lead a man to become very pious and a saint but he is unfortunate in this venture to become a saint due to his habit of drinking.

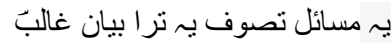

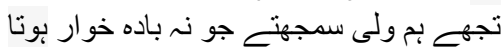

$$
\begin{aligned}
& \text { a saint we'd surely think you be if drunken you weren't found] (Ghalib 2018a) }
\end{aligned}
$$

The theme of self-praise is found common between Urdu poets and Shakespeare as most of the great poets do in the world, however, the distinguishing element in praising oneself among Urdu poets is that they use a specific term "Taa'lla" for [self-praise], widely used and poets use their name in poetry frequently which is known as 'Takhallus ${ }^{\text {' }}{ }^{\mathrm{v}]}$ pen name. Urdu poetry has developed a discourse of its kind around this subject. Mirza Ghalib and Mir Taqi Mir similarly praise themselves and their poetry in numerous ghazals. Ghalib, in one of the famous ghazals, admires his poetic talent and says:

$$
\begin{aligned}
& \text { بين اور بهى دنيا مين سخن ور بهت اجهم } \\
& \text { كيته بي كـ غالب كا بـ انس انداز بيان اور }
\end{aligned}
$$

[while there are many poets great, for in the world to speak but it is said that Ghalib does, possess a style unique] (Ghalib 2018b)

The element of self-praise makes him unique among all his contemporaries. No doubt, Ghalib has given Urdu poetry a new dimension of romanticism and idealism. Mir Taqi Mir (1722-23-1810), his contemporary and another renowned Urdu poet, pays homage to himself by praising his poetry, he says:

$$
\begin{aligned}
& \text { سار ـ عالم بر بوب ميل جهايا بوا }
\end{aligned}
$$

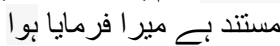

[I have dominated the whole world, whatever I say, it is credible'] (Mir 2018)

In this verse, Mir Taqi Mir claims his superiority of knowledge and credibility upon the literary world around him. The interesting fact in claiming his credible approach in Urdu poetry is that he is the pioneer in Urdu poetry to set it on modern trends and he has contributed a lot in shaping the Urdu language. His followers like Ghalib praised his talent and uniqueness of his poetry and paid homage to him in his ghazal and said: 'You are not the only master of 
Urdu, Ghalib. They say there used to be a Mir in the past' (Ghalib 2018). So self and praising others by name is a common theme in Urdu poetry. To praise himself by name is more prevalent in Urdu poetry.

At the same time, Shakespeare emphasizes the power of his poetic qualities and uniqueness by glorifying his poetry. He has conquered time as time is portrayed as a destructive force in his poetry and he through his poetic magic resisted against time and defeated it. According to Shakespeare, it's only through poetic talent that one can win time and emerge as victorious. In Sonnet 55, he says: "Or who his spoil of beauty can forbid? O, none, unless this miracle has might, That in black ink my love may still shine bright"(L. 5-7) metaphorically these lines suggest that only the miracle of his poetry will help his beloved to shine brightly forever due to the eternal inscription in the ink of his poetry.

Shakespeare, in his sonnet 55 while addressing his beloved, says that no piece of marble monuments will outlive my powerful poetry and you will glitter in my poetry more brightly than that 'unswept stone' that from the disrespect of time has become ugly. He further says that death will destroye everything but on the day of judgement you will rise as immortal in my poem (Sonnet 55) . In sonnet 19, he praises himself and reproaches devouring time for ravaging youth and beauty but keeps on saying, ' ye do thy worst, old-time, despite thy wrong/my love shall in my verse ever live young' (Sonnet 19). This whole sonnet and many others have a similar theme of self-praise and glorification of his own poetry.

Another theme equally famous and common in Shakespearean and Urdu poetry of the $19^{\text {th }}$ century is music. It is considered to have been awarded from the highest source-divine intervention. In Shakespeare's plays and sonnets, music holds a very important place. It is taken as a truth and the farther one goes from this truth and knowledge, the farther one is considered from the morality, understanding of the soul, and ethical refinement. His excessive use of music is the evidence of his familiarity with Neo-platonic and classical views of the moral nature of music as Catherine Dunn (1969) states that Shakespeare's views about music were mostly based on the musical theories of Plato and Pythagoras, the Greek philosophers and his contemporary Roman theologian and philosopher Boethius. Boethius has divided music into three categories; music of spheres, music that signifies the harmony between the human soul and body, and the last one is the instrumental performance of music. So the first two branches are the representatives of speculative or theoretical music, while the third one represents practical music. The views of the Puritan critics of the sixteenth and early seventeenth centuries consider theoretical music dangerous as according to them, it promoted sensuous and worldly pleasure only and the modern critics argue that Shakespeare has incorporated with Neo-platonic and classical theories of music but he also shows the power and significance of music in his writings (Dunn 1969: 391). In Twelfth Night, Shakespeare remarks that music is as important in life as food for survival. It provides solace and festive sentiments to the melancholic hearts. In the very beginning, he writes, "If music is the food of love, play on. Give me excess of it that, surfeiting, the appetite may sicken, and so die' (Act1, Sc. 1, Line: 1-3). These lines show the Duke's idea of finding a cure for his disease of insanely in love with a rich and resistant woman and find himself sick with his obsession with love and passion. According to Thelma N. Greenfield (1966), Shakespeare has successfully made music a part of his narrative to describe and delineate the situation and character and to present it in the development of the thematic argument ${ }^{28}$. Shakespeare relates music to character development and remarks that a person who doesn't know the importance and how to enjoy the music in life keeps a malevolent 
character. He calls such a person untrustworthy, treacherous, disloyal, and immoral. In his play The Merchant of Venice, Shakespeare writes that;

The man that has no music in himself,

Nor is not mov'd with concord of sweet sounds,

Is fit for treason, stratagem, and spoils;

The motion of his spirit are dull as night,

And his affections dark as Erebus;

Let no such man be trusted. Mark the music. (Act V, Sc. I)

In his historical play Richard II, Shakespeare uses the power of music on human psychology and emotions which Boethius refers to as 'musica humana' [subjective music of the soul], and King Richard in his last speech refers to the medical powers of music while saying;

This music mads me, let it sound no more,

For though it have holp madmen to their wits,

In me, it seems it will make wise men mad. (Act V, Sc. V)

Similarly, in Troilus and Cressida, Shakespeare shows the relationship between music and the human psyche by comparing a bad and untuned string to an immoral act. He takes both of them as pieces of disproportionate attributes lacking in harmony and balance. He writes, 'take but degree away, untune that string and hark what discord follows. Each thing meets in mere oppugnancy' (Act I, Sc. III).

According to J. M. Nosworthy (1958), Shakespeare marks the climax of his philosophy of speculative music in The Tempest, as this play doesn't carry the steady progression through the Romances. He further remarks that Pericles is "retrograde in dealing with music that it has non-adhesive elements whose presence or exclusion makes no or little difference in play" (Nosworthy 1958: 66) so the play deals with the philosophical concept of music in a specific way. However, the matter is different in Cymbeline, as the music plays a vital role in the concluding part of the play. In this play, musical instruments played by gods become the symbol of the reconciliation of both the divine and the human, since the platonic image of the world in the shape of the musical performance of gods. In another play, The Winter's Tale, like in Cymbeline, the attention is paid more to the pastoral and traditional elements of music. The element of music is organic in nature here but it is more practical than theoretical as it can be seen in the last two acts it is a symbol of reconciliation and restoration.

For Urdu poets, music and miracles of musical philosophy are associated with harmony and beauty and relate closely to the Platonic sense of health and goodness. According to Viitanaki, the music in Urdu poetry represents spiritual and Sufi thoughts as several poets, scholars and Sufis alike have selected to belittle the significance of music in the quest and attribute to it only instrumental value. Nevertheless, the participants are hardly immune to the aesthetic pleasure created by a combination of fine music and well-selected poems (Viitamäki 2015: 311). Mirza Ghalib in his ghazal, "na gul-e-naghma hun na pardah-e-saaz" translated as [No flower of song, no fretting of a guitar] by Andrew McCord, remarks in a similar way to Shakespeare on the ability of music to influence the lives of people and determine their attitude and lifestyle (McCord 2014). In this respect, readers of Urdu and English literature can find how the theme of music is common in both languages and share virtually identical views based on the significance of music for elevating the moral grievances of human beings. In both Shakespeare's works and Urdu poetry, the inspirational comparison among human life, music, 
and sentiments suggests that the slightest mistake or disorder/break of the notes of life's proportions and their conduct would turn the happy life into a mournful regret just like sweet music into sour cacophony. In another ghazal, Mirza Ghalib says, [I die at that sound, my head would fly away from me, But let me hear her tell my scourge, "Try some other blows."] (McCord 2014) and the fair and dainty human relations are changed to harsh and unbearable connections the same as the slightest mistake in numbers of proper proportions in life's conduct.

To conclude the discussion based on a comparison of selected works of Shakespeare and Urdu poetry of the $19^{\text {th }}$ century regarding ideas and themes, the authors conclude the basic purpose behind this essay and suggest some further ideas to be explored in the future in this context. This paper shows that it is possible to have a similarity of intellection, ideas, and thought among intellectuals of the world as 'great minds think alike' irrespective of far off lands, cultures, and ethnicity. They are universal mirrors of humanity and well advocated and reflected their ideas, liking and disliking, an enriched literary world with precious poetry, quotations, lofty ideas, deep wisdom, and insightful message to the readers of various cultures. This comparative study helps us to understand the concepts of love, morality, life, death, and beauty or in any negative emotions like jealousy and pride, etc. beyond specific boundaries. The more comparative studies of great writers and their works in different regions and languages have been conducted, the more readers understand how literature is a reflection of universal ideas and thoughts.

\section{References}

Abbasi, Zill-e Abbas. Ed. Kulliyat-e-Mir, Delhi, Ilmi Majlis, Vol. I, 1968, p. 616. She occurs in the Fourth Divan, composed before 1794, though after 1785.

Ben Amor, Z. "Mapping Sight and Blindness in the King Lear(s) of William Shakespeare and Roberto Ciulli: Towards a Poly-Optic Reading”. International Review of Literary Studies, vol. 2, no. 2, Dec. 2020, pp. 14-33, https://irlsjournal.com/ojs/index.php/irls/article/view/21.

Dunn, Catherine M. "The Function of Music in Shakespeare's Romances." Shakespeare Quarterly, vol. 20, no. 4, 1969, pp. 391-405. JSTOR, JSTOR, www.jstor.org/stable/2868536.

Emerson, Ralph Waldo. Works of Ralph Waldo Emerson. Edited with an introduction by J.P E.W. Cole Melbourne, 1900.

Ghalib, Mirza. Rekhta-poetry-collection-online. Retrieved on April 13, 2018. See https://www.rekhta.org/poets/mirza-ghalib

Gorakhpuri, Majnun "Mir aur Ham”, in M. Habib Khan, (Ed.), Afkar-e Mir, Delhi, Abdul Haq Academy, 1996 [1967], p. 196.

Graham, George Farquhar Irving. The life and work of Sir Syed Ahmed Khan (New and revised ed., reprinted / with a new introduction by Zaituna Y. Umer). Oxford University Press, Karachi; London, 1974 
Haq, Maulvi Abdul. Intikhab ..., Delhi, Anjuman Taraqqi-e Urdu (Hind), 1945 [1929], pp. 16, 31.

Kemp, Peter. (Ed.) The Oxford dictionary of literary quotations. New York: Oxford UP. 2004. p. 272

Kochar, D. S. "Conceptualising Love: A Reading of Selected African Love Poetry:

Conceptualising Love". International Review of Literary Studies, vol. 2, no. 2, Dec. 2020, pp. 1-13, https://irlsjournal.com/ojs/index.php/irls/article/view/31.

Manikpuri. Jaleel. Rekhta-poetry-collection-online. Retrieved on February 01, 2018. See https://www.rekhta.org/poets/jaleel-manikpuri

McCord, Andrew. "Four Ghazals by Mirza Ghalib". Caravan Magazine February 2014 retrieved from http://www.caravanmagazine.in/poetry/four-ghazals-mirza-ghalib

Mir, Taqi, Mir. Rekhta-poetry-collection-online. Retrieved on March 13, 2018. Sees https://www.rekhta.org/couplets/saare-aalam-par-huun-main-chhaayaa-huaa-mirtaqi$\underline{\text { mir-couplets-3?lang }=\text { ur }}$

Nosworth, James Mansfield. "Music and Its Function in the Romances of Shakespeare", Shakespeare Survey, New Zeland, 1958, p. 66.

Shakespeare, William. Twelfth Night. Retrieved on March 21, 2018. See http://shakespeare.mit.edu/twelfth_night/index.html

Shakespeare, William. Antony and Cleopatra. Retrieved on March 01, 2018. See http://shakespeare.mit.edu/cleopatra/index.html

Shakespeare, William. Richard II. Retrieved on January 15, 2018. See http://shakespeare.mit.edu/richardii/index.html

Shakespeare, William. Sonnet 130 Retrieved on March 01, 2018. See http://shakespeare.mit.edu/Poetry/sonnet.CXXX.html

Shakespeare, William. Sonnet 146. Retrieved on April 01, 2018. See http://shakespeare.mit.edu/Poetry/sonnet.CXLVI.html

Shakespeare, William. Sonnet 19. Retrieved on March 15, 2018. Sees http://shakespeare.mit.edu/Poetry/sonnet.XIX.htm

Shakespeare, William. Sonnet55. Retrieved on May 12, 2018. Sees http://shakespeare.mit.edu/Poetry/sonnet.LV.html

Silver, Brian. The Noble Science of the Ghazal: The Urdu Poetry of Mirza Ghalib, (New Delhi, Manohar, 2015). Heavily revised and expanded, 2016. 
Viitamäki, M. "Where Lovers Prostrate: Poetry in the Musical Assemblies of Chishti Sufis". Studia Orientalia Electronica, Vol. 107, July 2015, pp. 311-44, https://journal.fi/store/article/view/51793

Waller, Frederick O. "The Use of Linguistic Criteria in Determining the Copy and Dates for Shakespeare's Plays". In Pacific Coast Studies in Shakespeare, edited by Waldo F. McNeir and Thelma N. Greenfield, 1-9. Eugene, OR: University of Oregon Books, 1966.

Zafar, Bahadur Shah. Rekhta-poetry-collection-online. Retrieved on January 25, 2018. See https://www.rekhta.org/poets/bahadur-shah-zafar

Zauq, Sheikh Ibrahim. Rekhta-Poetry-Collation-Online, Retrieved on January 10, 2018. See https://www.rekhta.org/poets/sheikh-ibrahim-zauq 